DOI: https://doi.org/10.24127/ajpm.v9i4.3172

\title{
PENGEMBANGAN LEMBAR KERJA PESERTA DIDIK (LKPD) BERBASIS HIGHER ORDER THINKING SKILL (HOTS)
}

\author{
Lucy Asri Purwasi ${ }^{*}$, Nur Fitriyana ${ }^{2}$ \\ ${ }^{1 *}, 2$ Pendidikan Matematika STKIP PGRI Lubuklinggau, Indonesia \\ ${ }^{*}$ Corresponding author \\ E-mail: $\underline{\text { asripurwasi@gmail.com }}^{\left.1^{*}\right)}$
}

Received 19 October 2020; Received in revised form 05 December 2020; Accepted 20 December 2020

\begin{abstract}
Abstrak
Tujuan penelitian ini adalah untuk mengembangkan lembar kerja peserta didik (LKPD) berbasis higher order thinking skill (HOTS) yang dapat memfasilitasi siswa dalam melatih kemampuan berpikir tingkat tingginya. Metode penelitian yang digunakan merupakan penelitian dan pengembangan. Proses pengembangan LKPD diadaptasi dari model pengembangan 4-D (Four-D Models) yang terdiri dari pendefinisian (define), perancangan (design), pengembangan (develop), dan penyebaran (disseminate). Tahap pendefinisian meliputi analisis awal-akhir siswa, analisis tugas, analisis konsep dan spesifikasi tujuan. Tahap perancangan terdiri dari penyusunan tes, pemilihan media, dan pemilihan format. Tahap pengembangan terdiri dari uji kevalidan, kepraktisan dan keefektifan. Tahap penyebaran ini dilakukan dengan membagikan LKPD berbasis HOTS ke sekolah lain, selanjutnya siswa diminta untuk mengisi lembar angket respon terhadap LKPD yang dibagikan. Berdasarkan hasil penilaian validasi diperoleh skor rata-rata, yaitu aspek materi sebesar 3,73 dengan kategori valid, aspek konstruksi/media sebesar 4,28 dengan kategori sangat valid dan aspek bahasa sebesar 4,06 dengan kategori valid. Hasil penilaian kepraktisan siswa diperoleh skor rata-rata sebesar 4,15 dengan kategori praktis dan kepraktisan guru sebesar 3,60 dengan kategori praktis. Selanjutnya, hasil penilaian keefektifan melalui tes HOTS menunjukkan persentase ketuntasan secara klasikal sebesar 86,7\% dan respon siswa menunjukkan respon positif terhadap LKPD. Hasil penilaian tes menunjukkan rata-rata pretes diperoleh 30,76, sedangkan postes diperoleh 74,09. Artinya, terdapat peningkatan rata-rata nilai kemampuan berpikir tingkat tinggi dari pretes ke postes dalam ujicoba lapangan.
\end{abstract}

Kata kunci: HOTS; LKPD; Model 4-D; Penelitian dan Pengembangan.

\begin{abstract}
The purpose of this study was to develop worksheets based on higher order thinking skills that facilitate students in practicing their higher order thinking skills. The research method used is research and development. The worksheet development process is adapted from the 4-D model which consists of define, design, develop, and disseminate. The defining stage includes preliminary-final analysis, task analysis, concept analysis and goal specification. The design stage consists of composing tests, selecting media, and selecting formats. The development stage consists of testing the validity, practicality and effectiveness. The dissemination stage was carried out by distributing worksheets based on higher order thinking skills to other schools, then students were asked to fill out a questionnaire response to the worksheets that were distributed. Based on the results of the validation assessment, an average score was obtained, namely the material aspect was 3,73 with the valid category, the construction / media aspect was 4,28 with the very valid category and the language aspect was 4,06 with the valid category. The results of the student practicality assessment obtained an average score of 4,15 with the practical category and the teacher's practicality of 3,60 with the practical category. Furthermore, the results of the effectiveness assessment through the higher order thinking skill test showed a classical completeness percentage of $86,7 \%$ and student responses showed a positive response to the worksheet. The results of the test assessment showed that the pretest average was 30,76, while the post-test was 74,09. That is, there is an increase in the average value of higher order thinking skills from pretest to posttest in field trials.
\end{abstract}

Keywords: Four-D Model; HOTS;research and development; worksheet.

This is an open access article under the Creative Commons Attribution 4.0 International License 


\section{PENDAHULUAN}

Pendidikan matematika di era revolusi industri 4.0 diarahkan untuk pengembangan kemampuan matematis yang mengacu pada abad-21. Menurut Ariyana et al. (2018) pembelajaran abad 21 menggunakan istilah yang dikenal sebagai 4Cs (critical thinking, communication, collaboration, and creativity), adalah empat keterampilan yang telah diidentifikasi sebagai keterampilan abad ke-21 (P21) sebagai keterampilan sangat penting dan diperlukan untuk pendidikan abad ke21. Dimana keempat bagian tersebut merupakan bagian dari kemampuan berpikir tingkat tinggi atau higher order thinking skill (HOTS). López \& Whittington (2001) menyatakan bahwa berpikir pada tingkat yang lebih tinggi dari kognisi adalah keterampilan yang sangat diperlukan dalam proses pembelajaran. Selanjutnya, Ramos et al. (2013) pemikiran tingkat tinggi pada dasarnya berarti pemikiran yang terjadi di tingkat yang lebih tinggi dari tingkatan pemrosesan kognitif. HOTS meliputi aspek pengetahuan yang mencakup indikator memahami, menerapkan, menganalisis dan mengevaluasi (Anderson et al., 2001; Brookhart, 2010; Kusaeri et al., 2018; Tonra et al., 2019; Kristanto \& Setiawan, 2020)

HOTS atau kemampuan berpikir tingkat tinggi merupakan kemampuan ranah kognitif yang telah tercantum dan menjadi perhatian dalam kurikulum 2013 (Masitoh \& Aedi, 2020; Faiqoh et al., 2019). Implementasi kurikulum 2013 versi revisi saat ini sudah mengacu pada perangkat dan proses pembelajarannya berbasis HOTS. Sejalan dengan hal ini menurut Zulkardi \& Putri (2020) kurikulum 2013 edisi revisi menekankan pada penggunaan soal yang menuntut kemampuan berfikir tingkat tinggi (HOTS) dalam pembelajaran yang kolaboratif.

Sehingga, diperlukan perangkat pembelajaran yang salah satunya yaitu lembar kerja peserta didik (LKPD) yang memang khusus disusun berdasarkan karakteristik HOTS. Para guru memahami ada revisi dalam kurikulum 2013 diantaranya harus dapat mengembangkan HOTS dalam kegiatan pembelajaran termasuk dalam pengembangan instrumen penilaiannya, tapi mereka mengalami kesulitan dalam merumuskan indikator yang ada dalam HOTS menjadi instrumen penilaian (Hanifah, 2019).

Berdasarkan hasil observasi dan wawancara dengan guru bidang studi matematika dan beberapa siswa di SMP Negeri 5 Kota Lubuklinggau diperoleh informasi bahwa masih minim sekali penyediaan LKPD berbasis HOTS yang dikembangkan secara mandiri oleh para guru. Dalam proses pembelajaran hanya berpatokan pada satu buku ajar saja. Menurut Hersandi et al. (2017) buku tidak serta merta menjadi bahan ajar yang paling disukai para siswa karena buku cenderung terlalu banyak materi dan penyajian gambar yang membuat siswa kurang tertarik untuk membaca. Selain itu, dalam penerapan Kurikulum 2013 harus didukung dengan berbagai perangkat pembelajaran yang secara aktif dapat mengembangkan peserta didik (Umbaryati, 2016). Dalam mencapai target sesuai indikator keberhasilan dalam pembelajaran, bahan ajar yang digunakan guru seharusnya disertai lembar kegiatan peserta didik (LKPD) (Prastowo, 2014).

Pemahaman konsep siswa terhadap materi lingkaran masih kurang dari $50 \%$ dan siswa belum memiliki pemahaman yang baik tentang materi lingkaran. Siswa hanya menghafal rumus yang diberikan dalam 
mengerjakan soal, sehingga banyak kekeliruan dalam mengaplikasikan rumus keliling dan luas lingkaran. Soal yang diberikan kepada siswa merupakan soal rutin atau memiliki tingkat kesukarannya yang mudah. Sehingga saat siswa diberikan soal yang pengerjaannya sedikit berbeda maka siswa mengalami kesulitan. Begitupun, pada pemberian masalah siswa masih banyak belum memahami maksud dari permasalahan itu. Hal ini menjadi salah satu faktor HOTS siswa masih tergolong sangat rendah. Megawati et al. (2020) menyatakan bahwa kemampuan siswa Indonesia dalam menyelesaikan soal-soal yang menuntut proses berpikir tingkat tinggi masih sangat kurang.

LKPD merupakan salah satu sumber belajar yang dikenal pada kurikulum 2013 yang digunakan untuk membantu para guru dalam melatih keterampilan siswa dalam menemukan konsep-konsep melalui langkah kerja maupun permasalahan yang disediakan beserta dilengkapi dengan teknik penilaiannya. Penggunaan LKPD sebagai alat untuk membantu siswa dalam proses belajar di sekolah, karena di dalamnya terdapat materi yakni ringkasan dari berbagai sumber buku yang relevan sehingga proses pembelajaran efektif pada waktu yang dibutuhkan yang mana didalamnya terdapat beberapa materi pembelajaran dan latihan soal serta petunjuk kegiatan pembelajaran (Dewi \& Susilowibowo, 2016; Sari \& Wulandari, 2020). Melalui pengembangan LKPD berbasis HOTS, diharapkan dapat menciptakan proses pembelajaran bernuansa HOTS dan memfasilitasi siswa dalam melatih kemampuan berpikir tingkat tingginya. Terutama dalam pokok bahasan geometri. Geometri adalah salah satu pokok bahasan dari matematika yang sangat penting diberikan kepada peserta didik karena aplikasinya dalam kehidupan sehari-hari (Manalu \& Zanthy, 2020).

Salah satu bagian sub pokok bahasan dari geometri adalah lingkaran. Berdasarkan penelitian Ernawati \& Sutiarso (2020) menunjukkan bahwa faktor kesulitan dalam menyelesaikan soal matematika berkategori HOTS pada materi keliling dan luas lingkaran adalah siswa belum memahami apa yang disebut masalah, siswa tidak mampu menyerap informasi dengan baik, siswa tidak memahami materi sepenuhnya, kelemahan konsep prasyarat yang dimiliki oleh siswa, kurangnya pengalaman soal matematika berkategori HOTS, kurangnya pengalaman siswa dalam mengerjakan materi pelajaran cerita, dan siswa tidak cermat dan teliti dalam proses pengerjaan.

Adapun penelitian relevan yang pernah dilakukan terkait pengembangan bahan ajar maupun LKPD berbasis HOTS, yaitu (Khotimah \& Sari, 2020) menunjukkan LKPD berbasis higher order thinking skills (HOTS) pada materi Sistem Persamaan Linear Dua Variabel (SPLDV) menggunakan konteks lingkungan yang dikembangkan memenuhi aspek kevalidan dan kepraktisan yang baik sehingga layak digunakan dalam proses pembelajaran matematika. Selanjutnya oleh Utari et al. (2017) menunjukkan bahwa LKPD matematika berorientasi scientific approach yang dihasilkan valid, praktis dan efektif dan dapat meningkatkan HOTS siswa dengan persentase 79,41\%. Anisah \& Lastuti (2018) menyatakan melalui pengembangan modul pembelajaran matematika berbasis HOTS dapat meningkatkan kemampuan pemecahan masalah matematis mahasiswa. Selanjunya, Supadma et al. 
DOI: https://doi.org/10.24127/ajpm.v9i4.3172

(2019) menunjukkan bahwa LKPD berbasis aktivitas HOT yang dikembangkan dengan skor kevalidan sebesar 4,70 dengan kualifikasi sangat baik. Kaitannya dari beberapa hasil penelitian yang telah dilakukan sebelumnya maka diperlukan pengembangan LKPD berbasis HOTS pada materi lingkaran.

\section{METODE PENELITIAN}

Jenis penelitian yang dilakukan adalah penelitian dan pengembangan (Research and Development). Populasi dalam penelitian ini adalah siswa kelas VIII SMP Negeri 5 Kota Lubuklinggau, yang terdiri dari 6 kelas. Pemilihan sampel dilakukan dengan teknik random sampling. Sampel terpilih adalah kelas VIII-2 yang terdiri dari 22 orang siswa. Prosedur penelitian pengembangan LKPD diadaptasi dari model pengembangan perangkat pembelajaran 4-D yang dikembangkan oleh Thiagarajan, Dorothy S. Semmel, dan Melvyn I (Trianto, 2009) yang secara umum terdiri dari 4 tahap yaitu pendefinisian (define), perancangan (design), pengembangan (develop), dan penyebaran (disseminate).

Tahap pendefinisian (define). Tahap ini bertujuan menetapkan dan mendefinisikan syarat-syarat dalam pembelajaran. Tahap ini diawali dengan analisis tujuan dari batasan materi, yang meliputi beberapa langkah pokok, yaitu: a) Analisis awal-akhir. Analisis awalakhir bertujuan untuk memunculkan masalah dasar yang dihadapi dalam pembelajaran, b) analisis tugas, c) analisis konsep dan d) spesifik tujuan. Tahap perancangan (design). Tujuan tahap ini adalah untuk menyiapkan prototipe perangkat pembelajaran. Tahap ini terdiri dari 3 langkah, yaitu: (1) penyusunan tes. (2) Pemilihan media yang sesuai tujuan, untuk menyampaikan materi pelajaran. (3) Pemilihan format yang meliputi peta kebutuhan, kerangka LKPD, dan rancangan awal LKPD.

Tahap pengembangan (Develop). Tujuan tahap ini adalah untuk menghasilkan LKPD yang sudah direvisi berdasarkan masukan pakar. Tahap ini meliputi: (1) validasi oleh pakar diikuti dengan revisi, (2) simulasi yaitu kegiatan mengoperasikan rencana pengajaran, dan (3) uji coba terbatas dengan siswa yang sesungguhnya. Hasil tahap (2) dan (3) digunakan sebagai dasar revisi. Langkah berikutnya adalah uji coba lebih lanjut dengan siswa yang sesuai dengan kelas sesungguhnya. Tahap penyebaran (disseminate). Pada tahap ini merupakan tahap penggunaan LKPD yang telah dikembangkan pada skala yang lebih luas misalnya di kelas lain, di sekolah lain, oleh guru yang lain.

Teknik pengumpulan data yang digunakan adalah 1) Wawancara, kegiatan yang dilakukan berupa tanya jawab ke guru bidang studi matematika dan beberapa siswa terkait proses pembelajaran, sumber belajar yang digunakan, serta kesulitan siswa dalam belajar matematika terutama pada materi lingkaran. 2) Angket, terdiri dari angket validasi ahli, angket kepraktisan dan angket respon siswa. 3) Tes, diberikan merupakan soal-soal HOTS pada materi lingkaran. Instrumen tes digunakan untuk melihat keefektifan LKPD.

Instrumen penelitian yang digunakan meliputi 1) Pedoman wawancara, 2) lembar validasi LKPD, terdiri dari lembar validasi materi, lembar validasi konstruksi/media, dan lembar validasi bahasa, 3) lembar kepraktisan LKPD, terdiri angket kepraktisan yang diberikan kepada guru dan siswa dan 4) lembar keefektifan 
LKPD yang terdiri dari lembar tes HOTS dan respon sisw. Teknik analisis data yang dilakukan terdiri dari analisis lembar validasi LKPD, analisis angket kepraktisan siswa dan analisis keefektifan LKPD ditinjau dari hasil tes HOTS melalui pretes dan postes dan respon siswa pada uji coba lapangan.

Validasi LKPD diukur dengan menggunakan skala likert lima skala, dimulai dari skor 1, tidak sesuai sampai dengan skor 5 , sangat sesuai. Skor ratarata diperoleh dari penilaian validator, dapat dicari dengan menggunakan rumus (1).

$$
\bar{V}=\frac{\sum_{i=1}^{n} R A_{i}}{n}
$$

dengan $\bar{V}$ adalah skor rata-rata validitas, $R A_{i}$ adalah skor rata-rata validasi aspek ke- $i$, dan $\mathrm{n}$ adalah banyaknya aspek (Khabibah, 2006). Selanjutnya, mencocokkan rata-rata validitas $(\bar{V})$ dengan kriteria kevalidan LKPD pada Tabel 1.

Tabel 1. Kriteria validitas materi, media dan bahasa LKPD.

\begin{tabular}{ccc}
\hline No & $\begin{array}{c}\text { Interval } \\
\text { Kevalidan }\end{array}$ & $\begin{array}{c}\text { Kriteria } \\
\text { Kevalidan }\end{array}$ \\
\hline 1 & $\bar{V}>4,2$ & Sangat Valid \\
2 & $3,4<\bar{V} \leq 4,2$ & Valid \\
3 & $2,6<\bar{V} \leq 3,4$ & Cukup Valid \\
4 & $1,79<\bar{V} \leq 2,6$ & Kurang \\
& & Valid \\
& & Sangat \\
5 & $\bar{V} \leq 1,79$ & Kurang \\
& & Valid \\
\hline
\end{tabular}

selanjutnya revisi LKPD dilakukan sesua dengan saran dari validator sehingga diperoleh LKPD yang valid.

Data kepraktisan diperoleh dari hasil angket kepraktisan guru dan siswa. angket kepraktisan diukur menggunakan skala likert dimulai dari skor 1, tidak sesuai sampai dengan skor 5, sangat sesuai. Angket terdiri dari 20 pernyataan dengan jumlah 17 butir pernyataan positif dan 3 butir pernyataan negatif. Skor rata-rata kepraktisan guru dan siswa dihitung menggunakan rumus (2).

$$
\overline{\mathrm{P}}=\frac{\sum_{\mathrm{i}=1}^{\mathrm{n}} \mathrm{RA}}{\mathrm{n}}
$$

dengan $\overline{\mathrm{P}}$ adalah skor rata-rata kepraktisan, $R A_{i}$ adalah Skor rata-rata validasi aspek ke-i, $n$ adalah banyaknya aspek (Khabibah, 2006). Selanjutnya, mencocokkan rata-rata kepraktisan $(\overline{\mathrm{P}})$ dengan kriteria kepraktisan LKPD pada Tabel 2.

\begin{tabular}{|c|c|c|}
\hline No & $\begin{array}{c}\text { Interval } \\
\text { Kepraktisan }\end{array}$ & $\begin{array}{c}\text { Kriteria } \\
\text { Kepraktisan }\end{array}$ \\
\hline 1 & $\bar{V}>4,2$ & $\begin{array}{l}\text { Sangat } \\
\text { Praktis }\end{array}$ \\
\hline 2 & $3,4<\bar{V} \leq 4,2$ & Praktis \\
\hline 3 & $2,6<\bar{V} \leq 3,4$ & $\begin{array}{l}\text { Cukup } \\
\text { Praktis }\end{array}$ \\
\hline 4 & $1,79<\bar{V} \leq 2,6$ & $\begin{array}{l}\text { Kurang } \\
\text { Praktis } \\
\text { Sangat }\end{array}$ \\
\hline 5 & $\bar{V} \leq 1,79$ & $\begin{array}{l}\text { Kurang } \\
\text { Praktis }\end{array}$ \\
\hline
\end{tabular}

Tabel 2. Kriteria kepraktisan LKPD.

Data keefektifan diperoleh dari tes siswa yang meliputi pretes dan postes kemampuan berpikir tingkat tinggi siswa serta respon siswa. Tes terdiri dari 3 soal essay yang masingmasing soal memuat indikator HOTS. Hasil rata-rata tes HOTS siswa dihitung dengan menggunakan rumus (3).

$\bar{H}=\frac{\text { Skor yang diperoleh }}{\text { Skor Maksimal }} \times 100$

dengan $\bar{H}$ adalah nilai rata-rata hasil HOTS siswa. Selanjutnya, mencocokkan rata-rata nilai $(\overline{\mathrm{H}})$ dengan kriteria tingkat HOTS pada Tabel 3. 
DOI: https://doi.org/10.24127/ajpm.v9i4.3172

Tabel 3. Kriteria Tingkat HOTS

No Interval Nilai Kriteria

\begin{tabular}{ccc}
\hline 1 & $\bar{H} \geq 80$ & Sangat Baik \\
2 & $70 \leq \bar{H}<80$ & Baik \\
3 & $60 \leq \bar{H}<70$ & Cukup \\
4 & $50 \leq \bar{H}<60$ & Rendah \\
5 & $\bar{H}<50$ & Sangat \\
& & Rendah \\
\hline
\end{tabular}

Skor rata-rata angket respon siswa dihitung menggunakan rumus (3).

$$
\overline{\mathrm{R}}=\frac{\sum_{\mathrm{i}=1}^{\mathrm{n}} \overline{\mathrm{R}}_{\mathrm{i}}}{\mathrm{n}}
$$

dengan $\bar{R}$ adalah nilai rata-rata respon siswa, $\overline{\mathrm{R}}_{\mathrm{i}}$ adalah nilai rata-rata respon siswa ke- $i$, dan $n$ adalah banyak siswa. Selanjutnya, mencocokkan rata-rata respon $(\bar{R})$ dengan kriteria respon siswa pada Tabel 4.

Tabel 4. Kriteria Respon Siswa.

\begin{tabular}{ccc}
\hline No & $\begin{array}{c}\text { Interval } \\
\text { Kepraktisan }\end{array}$ & $\begin{array}{c}\text { Kriteria } \\
\text { Kepraktisan }\end{array}$ \\
\hline 1 & $\bar{R}>4,2$ & Sangat Baik \\
2 & $3,4<\bar{R} \leq 4,2$ & Baik \\
3 & $2,6<\bar{R} \leq 3,4$ & Cukup \\
4 & $1,79<\bar{R} \leq 2,6$ & Rendah \\
5 & $\bar{R} \leq 1,79$ & Sangat \\
& & Rendah \\
\hline
\end{tabular}

\section{HASIL DAN PEMBAHASAN}

Proses Pengembangan LKPD

1. Pendefinisian (define)

a. Analisis awal dan akhir

Pada tahap ini melakukan wawancara dengan guru bidang studi matematika dan beberapa siswa di SMP Negeri 5 Kota Lubuklinggau. Analisis awal-akhir dilakukan dengan tiga langkah yaitu observasi proses pembelajaran, wawancara dengan guru bidang studi matematika dan siswa, dan observasi perangkat pembelajaran yang digunakan. Berdasarkan hasil observasi dan wawancara dengan guru matematika kelas VIII dengan Ibu Eni Erlianti Hempi, S.Pd di SMP Negeri 5 Kota Lubuklinggau pada proses pembelajaran diketahui bahwa pembelajaran belum mengkondisikan siswa pada pembelajaran bernuansa HOTS. Proses pembelajaran masih melibatkan guru sebagai subjek yang aktif dalam menjelaskan materi, sehingga pembelajaran lebih menekankan pada teacher center.

Dalam menyelesaikan soal materi lingkaran masih menekankan pada hafalan rumus dibandingkan membangun pemahaman konsep siswa, sehingga siswa mudah lupa keliru dalam mengaplikasikan rumus keliling dan luas lingkaran dalam menyelesaikan soal yang diberikan. Siswa dibiasakan dengan soal rutin dan memiliki tingkat kesukarannya yang mudah. Sehingga saat siswa diberikan soal yang pengerjaannya sedikit berbeda maka siswa mengalami kesulitan. Begitupun, pada pemberian masalah siswa masih banyak belum memahami maksud dari permasalahan itu. Sejalan dengan hal ini Anugrah \& Pujiastuti (2020) menyatakan kesalahan siswa dalam menyelesaikan soal HOTS ialah sebagian siswa mengalami kesalahan membaca soal, kesalahan memahami soal, kesalahan transformasi dan kesalahan ketelitian karena tergesa-gesa sehingga menimbulkan kesalahan umum konsep, interpretasi data, proses algoritma dan kealpaan.

Pemahaman konsep siswa terhadap materi lingkaran masih kurang dari $50 \%$, artinya siswa masih kurang memiliki pemahaman yang baik tentang materi keliling dan luas lingkaran.Untuk dapat mengembangkan HOTS dalam pembelajaran terutama pada materi keliling dan luas lingkaran di kelas tidak hanya mampu dengan mengingat rumus, memahami, dan 
mengaplikasikannya saja, namun siswa juga haruss mampu menganalisis masalah-masalah matematis yang diberikan, mengevaluasi hasil pekerjaannya, dan menciptakan cara atau sudut pandang baru ataupun mengkreasikan pengetahuannya untuk memecahkan masalah yang dihadapi (Dosinaeng et al., 2019). Sumber belajar yang digunakan dari tahun ke tahun hanya berupa buku paket Kemdikbud 2013. Tidak ada bahan ajar penunjang lainnya yang mendapingi peserta didik dalam proses pembelajaran.

Selain itu, masih banyak siswa yang mendapatkan nilai matematika yang belum mencapai KKM yang ditetapkan sekolah, yaitu 70. Karena itu, perlu dikembangkan LKPD berbasis HOTS yang memuat permasalahan kehidupan sehari-hari dan langkahlangkah kerja sehingga menuntut siswa untuk selalu aktif dan secara mandiri menyelesaikannya. Melalui langkah kerja dalam LKPD akan mengarahkan siswa untuk menemukan konsep materi lingkaran. Menurut Wulandari \& Susanti (2019) menjelaskan lembar kegiatan peserta didik dipilih karena cukup mampu menyajikan materi pelajaran yang akan disampaikan dan disertai dengan latihan soal berbasis HOTS serta evaluasi yang cukup banyak. Soal-soal yang dikembangkan akan mengacu pada soal-soal yang berbasis HOTS dan mengikuti perkembangan kurukulum 2013 Revisi.

Analisis kurikulum yang digunakan di kelas VIII SMP Negeri 5 Kota Lubuklinggau adalah kurikulum 2013. Kurikulum 2013 disusun untuk meningkatkan keterampilan abad 21, menuntut para guru untuk menciptakan pembelajaran yang melibatkan kemampuan berpikir matematis siswa yang bernuansa higher order thinking skills (Yuliandini et al., 2019; Purwasi,
2019). Materi yang dikembangkan adalah materi lingkaran, hal ini berdasarkan kesimpulan dari hasil wawancara dengan guru pendidikan matematika dan siswa pada materi ini siswa sering mengalami kesulitan dan kekeliruan dalam memahami unsurunsur, keliling dan luas lingkaran.

Dalam kurikulum tersebut tercantum kompetensi dasar: a) Mengidentifikasi unsur, keliling, dan luas dari lingkaran b) Menyelesaikan permasalahan nyata terkait penerapan keliling dan luas lingkaran. Indikator yang terdiri dari: a) Mengamati unsurunsur lingkaran, b) Mengkritisi/menalar hubungan antar unsur-unsur lingkaran, c) Menemukan rumus menentukan keliling lingkaran, d) Menemukan rumus menentukan luas lingkaran, dan e) Menyelesaikan permasalahan nyata terkait keliling dan luas lingkaran. Pemilihan pendekatan yaitu dengan pembelajaran bernuansa HOTS.

\section{b. Analisis Tugas}

Tahap ini merupakan tugas pokok yang harus dikuasai siswa agar dapat mencapai kompetensi yang ditentukan. Sesuai dengan kurikulum 2013 mewajibkan para guru untuk membiasakan siswa dalam proses pembelajaran HOTS, agar siswa terlatih kemampuan berpikir dan bernalarnya dimana indikator yang harus dikuasai oleh siswa meliputi menganalisis (C3), mengevaluasi (C4) dan mencipta (C6) yang juga disesuaikan dengan KI dan KD materi lingkaran. Berikut hal-hal yang disajikan pada LKPD yang dikembangkan melalui analisis tugas, yaitu 1) Isi tugas yang diberikan pada materi Lingkaran didasarkan pada pembelajaran bernuansa HOTS, dan b) Isi Tugas berisikan permasalahan kehidupan sehari-hari yang melatih penalaran dan indikator HOTS. 


\section{c. Analisis Konsep}

Tahap ini adalah analisis konsep materi lingkaran yang akan dikembangkan secara sistematis, yaitu unsur-unsur lingkaran, keliling lingkaran, luas lingkaran dan penerapan kehidupan sehari-hari materi lingkaran. Konsep pembelajaran yang dikembangakn juga disamakan dengan hasil analisis awalakhir, analisis siswa, analisis tugas dan pembelajaran bernuansa HOTS dan standar keterampian yang dicapai. Menurut Widana et al., (2018) Penilaian HOTS secara tidak langsung memberikan kontribusi pembelajaran yang positif untuk meningkatkan pemahaman konsep matematika.

\section{d. Spesifikasi Tujuan}

Tujuan pembelajaran dalam LKPD dapat dispesifikasikan sebagai berikut, 1) Mengamati unsur-unsur lingkaran; 2) Mengkritisi/menalar hubungan antar unsur-unsur lingkaran; 3) Menemukan rumus menentukan keliling lingkaran; 4) Menemukan rumus menentukan luas lingkaran; dan 5) Menyelesaikan permasalahan nyata terkait keliling dan luas lingkaran.

\section{Perancangan (Design)}

Tahapan perancangan yang dilakukan adalah sebagai berikut:

a. Penyusunan Tes

Penyusunan tes soal HOTS diberikan untuk melihat kemampuan awal siswa terhadap materi lingkaran dan kemampuan akhir setelah menggunakan LKS berbasis HOTS. Soal tes terdiri dari 3 soal essay yang masing-masing soal memuat 3 indikator HOTS. b. Pemilihan Media

Menurut Retnoasih mengungkapkan bahwa Pembelajaran HOTS diperlukan perencanaan terkait karakteristik materi, peserta didik dan dibutuhkan media pendukung pembelajaran. Sehingga perlu dilakukan perumusan pemilihan media pembelajaran yang tepat yang akan digunakan dalam mengerjakan permasalahan pada LKPD.

c. Pemilihan Format

1) Menyusun Peta Kebutuhan, hasil penyusunan peta kebutuhan LKPD memberikan keterangan tentang banyaknya LKPD yang harus dibuat.

2) Menyusun Kerangka LKPD, LKPD yang dikembangkan dalam penelitian ini adalah LKPD siswa yang terdiri dari tiga bagian yaitu bagian awal berisikan halaman sampul depan, halaman identitas LKPD, kata pengantar, daftar isi, petunjuk penggunaan LKPD, kompetensi dasar, tujuan pembelajaran, kata kunci, peta konsep, dan sejarah penemu. Bagian isi berisikan orientasi materi, lembar kegiatan, informasi pendukung, kesimpulan, menanya, latihan, merangkum, dan uji kompetensi. Bagian akhir berisikan daftar pustaka dan halaman sampul belakang.

3) Rancangan Awal LKPD

Desain awal LKPD disusun sesuai dengan pemilihan media dan format penyusunan LKPD. Adapun rancangan awal LKPD berbasis HOTS dapat dilihat pada Gambar 1. 
DOI: https://doi.org/10.24127/ajpm.v9i4.3172
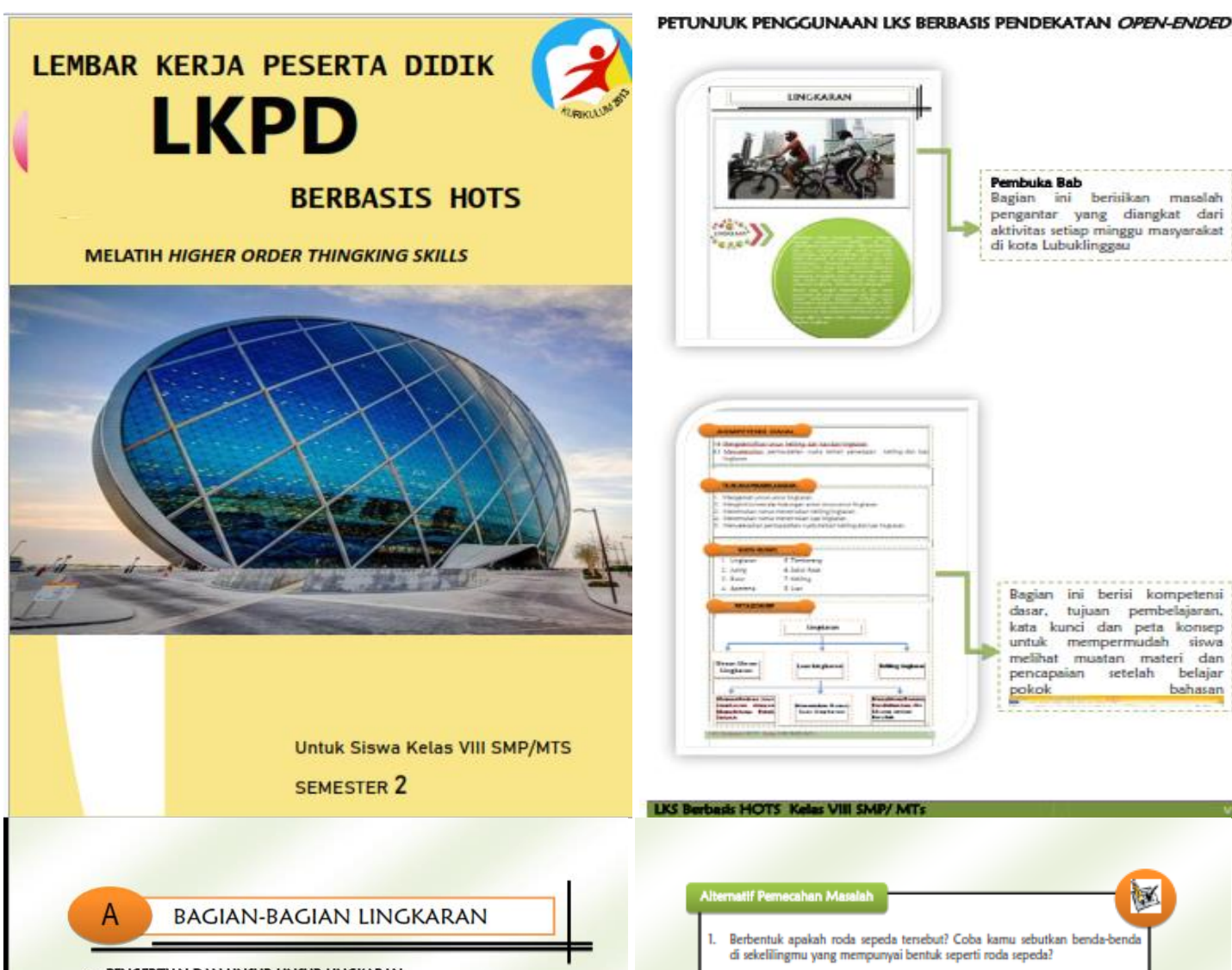

- pencertian dan UnSUR-unsur ungkaran

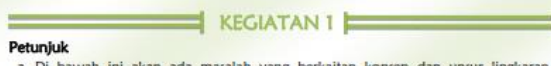

Petunjuk

Selesaikanlah.

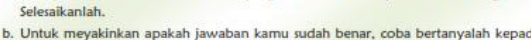

teman yang ada di sebelah kanan dan kirimu apa jawaban merteka. Jika kapabad

kamu berbeda dengan jawaban temanmu, tanyakan bagaimana ia mencar

jawabannya.
c. Jika sudah yakin dengan jawaban yang kamu peroleh, silahkan lanjutkan

遮 MASALAH 1

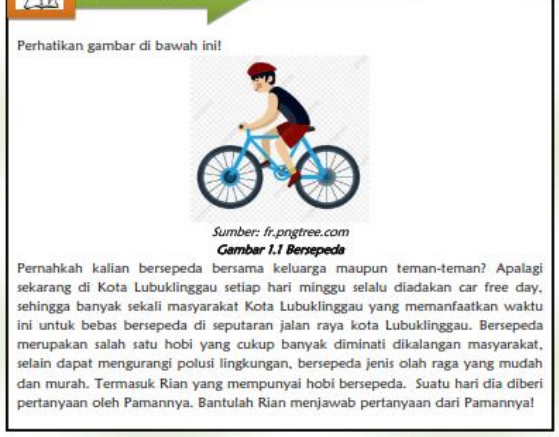

LSS Berbasts HOTS Kelas VIII SMP/MTS
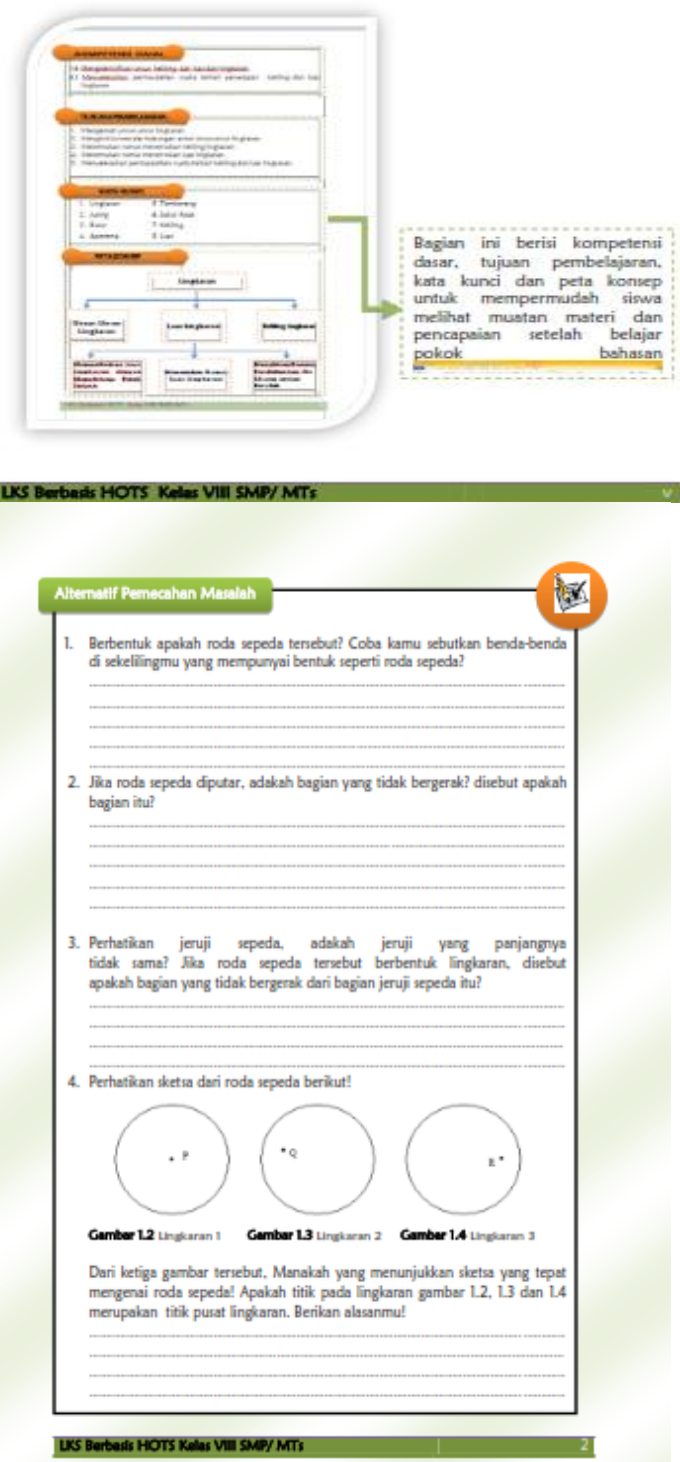

Gambar 1. Desain rancangan awal LKPD.

3. Pengembangan (develop)

1) Uji Kevalidan LKPD

Hasil indikator penilaian ahli materi dari kelayakan isi diperoleh skor ratarata sebesar 3,72, sedangkan skor ratarata pada kelayakan penyajian dan penilaian HOTS berturut-turut sebesar 3,91 dan 3,56. Skor rata-rata dari ketiga aspek penilaian materi sebesar 3,73 dengan kategori valid. Data analisis validasi materi dari para ahli dapat dilihat pada Tabel 5. 
DOI: https://doi.org/10.24127/ajpm.v9i4.3172

Tabel 5. Hasil validasi ahli materi.

\begin{tabular}{cccc}
\hline No & Indikator Penilaian & Rata-rata & Kategori \\
\hline $\mathbf{1}$ & Kelayakan Isi & 3,72 & Valid \\
$\mathbf{2}$ & Kelayakan Penyajian & 3,91 & Valid \\
$\mathbf{3}$ & Penilaian HOTS & 3,56 & Valid \\
& Rata-rata & 3,73 & Valid \\
\hline
\end{tabular}

Hasil indikator penilaian ahli media dari aspek kegrafikan, menurut BSNP meliputi ukuran LKPD diperoleh skor rata-rata sebesar 4,50, desain sampul LKPD dengan skor rata-rata sebesar 4,28 dan desain isi LKPD dengan skor rata-rata sebesar 4,06. Skor rata-rata dari ketiga aspek sebesar 4,28 dengan kategori sangat valid. Data analisis validasi media dapat dilihat pada Tabel 6.

Tabel 6. Hasil validasi ahli media

\begin{tabular}{cccc}
\hline No & Indikator Penilaian & Rata-rata & Kategori \\
\hline $\mathbf{1}$ & Ukuran LKPD & 4,50 & Sangat Valid \\
$\mathbf{2}$ & Desain Sampul LKPD $($ Cover $)$ & 4,28 & Sangat Valid \\
$\mathbf{3}$ & Desain isi LKPD & 4,06 & Valid \\
& Rata-rata & 4,28 & Valid \\
\hline
\end{tabular}

Hasil indikator penilaian ahli bahasa rekapitulasi aspek kelayakan bahasa, menurut BSNP meliputi aspek lugas dengan skor rata-rata sebesar 4,00 , aspek komunikatif dengan skor sebesar 4,00, aspek dialogis dan interaktif dengan skor rata-rata sebesar 4,00 , aspek kesesuaian dengan perkembangan peserta didik dengan skor rata-rata sebesar 4,00 dan kesesuaian dengan kaidah bahasa dengan skor rata-rata sebesar 4,40. Skor rata-rata dari ke lima aspek adalah sebesar 4,08 dengan kategori valid. Data analisis validasi bahasa dapat dilihat pada Tabel 7 .

Tabel 7. Hasil validasi ahli bahasa.

\begin{tabular}{|c|c|c|c|}
\hline No & Indikator Penilaian & Rata-rata & Kategori \\
\hline 1 & Lugas & 4,00 & Valid \\
\hline 2 & Komunikatif & 4,00 & Valid \\
\hline 3 & Dialogis dan interaktif & 4,00 & Valid \\
\hline 4 & Kesesuaian dengan perkembangan peserta didik & 4,00 & Valid \\
\hline 5 & $\begin{array}{c}\text { Kesesuaian dengan kaidah bahasa } \\
\text { Rata-rata }\end{array}$ & $\begin{array}{l}4,40 \\
4,08\end{array}$ & $\begin{array}{l}\text { Sangat Valid } \\
\text { Valid }\end{array}$ \\
\hline
\end{tabular}

Berdasarkan hasil validasi dari ketiga bagian yaitu materi, konstruksi/media dan bahasa secara umum dapat disimpulkan LKPD sudah layak untuk dilanjutkan ketahap kepraktisan. Setelah analisis uji validitas dilakukan menghasilkan draft II LKPD berbasis HOTS. b) Uji Kepraktisan LKPD berbasis HOTS

Uji kepraktisan dilakukan untuk mengetahui apakah bagian-bagian dalam LKPD praktis dan mudah digunakan oleh siswa dan guru sebagai pengguna. Ujicoba terbatas dilakukan terhadap 7 orang siswa. Hasil penilaian lembar kepraktisan siswa menunjukkan 
skor rata-rata sebesar 4,15 dengan kategori praktis. Hasil lembar kepraktisan guru menunjukkan skor rata-rata sebesar 3,60 dengan kategori praktis. Hasil ini menunjukan bahwa bagian-bagian pada LKPD dapat digunakan dengan baik. LKPD yang telah diuji kepraktisan dengan menghasilkan darft III dapat digunakan dalam proses pembelajaran yang sesungguhnya. Sejalan dengan pendapat Nurhikmayati \& Jatisunda (2019) ketika penilaian siswa terhadap bahan ajar yang dikembangkan sudah cukup baik maka bahan ajar dapat digunakan dalam proses pembelajaran di kelas.

\section{c) Uji Keefektifan LKPD Berbasis HOTS}

Selanjutnya, ujicoba lapangan dilakukan terhadap 22 orang siswa kelas VIII SMP Negeri 5 Lubuklinggau. Keefektifan LKPD dianalisis dari hasil pretes dan postes HOTS siswa dan respon siswa. LKPD yang dikembangkan dikatakan efektif apabila telah memenuhi persentase kriteria ketuntasan minimal (KKM) atau ketuntasan secara klasikal dan respon positif siswa (Prasetyo, 2012). Selain itu Hasil pretes menunjukkan rata-rata nilai HOTS siswa sebesar 30,76 dengan kategori rendah. Persentase ketuntasan belajar siswa pada pretes adalah $0 \%$. Selanjutnya, hasil postes menunjukkan rata-rata nilai HOTS siswa sebesar 30,76 dengan kategori rendah. Hasil postes menunjukkan peningkatan terhadap HOTS siswa dengan rata-rata nilai sebesar 74,09 dengan kategori baik dan persentase rata-rata ketuntasan belajar siswa adalah 86,4\%. Hasil angket respon dengan rata-rata skor respon siswa diperoleh adalah 4,11 dengan kategori baik. Artinya, siswa menunjukkan respon positif dalam penggunaan LKPD berbasis HOTS pada materi lingkaran. Hal ini menunjukkan LKPD yang digunakan efektif dan dapat memfasilitasi HOTS siswa.

$\begin{array}{ccc}\text { LKPD } & \text { Berbasis } & \text { HOTS layak } \\ \text { digunakan } & \text { dan } & \text { memberikan }\end{array}$
peningkatan pada HOTS siswa terutama pada materi Lingkaran. Dari hasil keseluruhan analisis data diproleh produk akhir LKS yang valid, praktis dan efektif dan dapat digunakan dalam proses pembelajaran di kelas. Sejalan dengan hasil penelitian Apino \& Retnawati (2017) Desain pembelajaran yang dikembangkan secara umum berorientasi HOTS berpengaruh positif dalam (1) melibatkan siswa dalam kegiatan pemecahan masalah non rutin; (2) memfasilitasi siswa untuk mengembangkan kemampuan menganalisis dan mengevaluasi (berpikir kritis) dan kemampuan berkreasi (berpikir kreatif); dan (3) mendorong siswa untuk membangun pengetahuannya sendiri.

\section{Tahap Penyebaran}

Pada tahap ini melakukan penyebaran LKPD berbasis HOTS ke SMP Negeri 8 Kota Lubuklinggau, selanjutnya siswa diminta untuk mengisi lembar angket respon terhadap LKPD yang dibagikan. Hasil rata-rata angket respon siswa yang diperolah sebesar 3,82 dalam kategori baik. Artinya, siswa menunjukkan respon positif terhadap LKPD berbasis HOTS. Hal ini sejalan dengan hasil penelitian Noprinda \& Soleh (2019) menunjukkan respons peserta didik terhadap LKPD berbasis higher order thinking skill (HOTS) dengan persentase sebesar 87\% dengan kriteria "sangat baik". Sehingga dapat dikatakan LKPD siap dipakai sebagai bahan ajar.

LKPD berbasis HOTS yang telah dikembangkan memberikan dampak teoritis dan praktis. Secara teoritis, hasil 
pengembangan LKPD ini dapat dijadikan sebagai salah satu acuan maupun rujukan bagi peneliti lain untuk mengembangkan bahan ajar terutama jenis LKPD berbasis HOTS. Secara praktis, LKPD dapat digunakan oleh guru dalam kegiatan pembelajaran untuk memfasilitasi kemampuan berpikir tingkat tinggi siswa kelas VIII pada materi lingkaran. Selanjutnya, LKPD yang dikembangkan dapat memotivasi para guru untuk membuat dan mengembangkan secara mandiri bahan ajar yang menarik dan bermakna untuk siswa. LKPD juga dapat digunakan siswa sebagai sumber belajar matematika bagi siswa di kelas ataupun sebagai sarana belajar mandiri di rumah. Karena LKPD ini dilengkapi dengan lembar kegiatan yang bisa dikerjakan secara kelompok maupun diskusi, dan juga dilengkapi dengan informasi pendukung untuk membantu siswa dalam menyelesaikan permasalahan.

\section{KESIMPULAN DAN SARAN}

Dari hasil penelitian dan pengembangan yang dilakukan menghasilkan LKPD berbasis HOTS yang telah memenuhi aspek valid, praktis dan efektif dan dapat memfasilitasi siswa dalam melatih kemampuan berpikir tingkat tingginya. Pengembangan produk LKPD ini masih terbatas pada satu materi dan analisis tahap penyebaran ke sekolah lain hanya pada penyebaran angket respon. Oleh karena itu, diharapkan adanya tindak lanjut baik itu dari para guru maupun peneliti lainnya untuk mengembangkan bahan ajar dengan konteks dan materi yang berbeda. Selain itu, perlu dilakukan penelitian lebih lanjut untuk melihat keefektifan dan pengaruh penggunaan LKPD berbasis HOTS ini dalam proses pembelajaran di sekolah lain.

\section{DAFTAR PUSTAKA}

Anderson, L. W., Krathwohl, D. R., Airasian, P. W., Cruikshank, K. A., Mayer, R. E., Pintrich, P. R., Raths, J., \& Wittrock, M. (2001). A Taxonomy for Learning, Teaching, and Assessing: A revision of Bloom's Taxonomy of Educational Objectives. Longman.

Anisah, \& Lastuti, S. (2018). Pengembangan Bahan Ajar berbasis HOTS untuk Meningkatkan Kemampuan Pemecahan Masalah Matematis Mahasiswa. Jurnal Kreano: Jurnal Matematika Kreatif-Inovatif, 9(2), 191-197.

Anugrah, A., \& Pujiastuti, H. (2020). Analisis Kesalahan Siswa dalam Menyelesaikan Soal HOTS Bangun Ruang Sisi Lengkung. Jurnal Pendidikan Matematika, 11(2), 213-225. https://doi.org/10.36709/jpm.v11i2 .11897

Apino, E., \& Retnawati, H. (2017). Developing Instructional Design to Improve Mathematical Higher Order Thinking Skills of Students. Journal of Physics: Conference Series, 812, 1-7.

Ariyana, Y., Pudjiastuti, A., Bestary, R., \& Zamroni. (2018). Buku Pegangan Pembelajaran Berorieantasi pada Keterampilan Berpikir Tingkat Tinggi. Direktorat Jenderal Guru dan Tenaga Kependidikan KEMDIKBUD.

Brookhart, S. M. (2010). How to Assess Higher-Order Thinking Skills in Your Classroom. ASCD.

Dewi, T. N. C., \& Susilowibowo, J. (2016). Pengembangan LKS dalam Rangka Menunjang Pembelajaran 
DOI: https://doi.org/10.24127/ajpm.v9i4.3172

Berbasis Scientific Approach pada Materi Laporan Keuangan Perusahaan Jasa. Jurnal Pendidikan, 4(3), 1-6.

Dosinaeng, W. B. N., Leton, S. I., \& Lakapu, M. (2019). Kemampuan Mahasiswa dalam Menyelesaikan Masalah Matematis Berorientasi HOTS. JNPM (Jurnal Nasional Pendidikan Matematika), 3(2), 250-264.

Ernawati, \& Sutiarso, S. (2020). Analisis Kesulitan Menyelesaikan Soal Matematika Kategori Higher Order Thinking Skills Menurut Tahapan Polya. Jurnal Penelitian Pembelajaran Matematika, 13(2), 178-195.

Faiqoh, A. N., Irianto, S., \& Anggoro, S. (2019). Pengembangan LKPD Matematika Berbasis Higher Order Thinking Materi Bangun Ruang Kelas V Sekolah Dasar. Jurnal Elementaria Edukasia, 2(2), 103106.

Hanifah, N. (2019). Pengembangan Instrumen Penilaian Higher Order Thinking Skill ( HOTS ) di Sekolah Dasar. Current Research in Education: Conference Series Journal, 1(1), 1-8.

Hersandi, M., Mahardika, I. K., \& Nuriman. (2017). Pengembangan Bahan Ajar Lembar Kerja Siswa (LKS) dalam Bentuk Brosur Untuk Pembelajaran IPA di SMP ditinjau dari Aspek Kegrafikaannya. Jurnal Pembelajaran Dan Pendidikan Sains, 2(1), 57-64.

Khabibah, S. (2006). Pengembangan Model Pembelajaran Matematika dengan Soal Terbuka untuk Meningkatkan Kreativitas Siswa SD. Disertasi tidak dipublikasikan. Surabaya: UNESA.

Khotimah, R. P., \& Sari, M. C. P. (2020). Pengembangan Lembar
Kerja Peserta Didik Berbasis Higher Order Thinking Skills (HOTS) Menggunakan Konteks Lingkungan. Jurnal Aksioma: Jurnal Program Studi Pendidikan Matematika, 9(3), 761-775.

Kristanto, P. D., \& Setiawan, P. G. F. (2020). Pengembangan Soal HOTS (Higher Order Thinking Skills) Terkait Dengan KonteksPedesaan. PRISMA: Prosiding Seminar Nasional Matematika, 3, 370-376.

Kusaeri, Sadieda, L. U., Indayati, T., \& Faizien, M. I. (2018). Developing an Assessment Instrument of Higher Order Thinking Skills in Mathematics with in Islamic Context. Journal of Physics: Conference Series, 1097(1). https://doi.org/10.1088/17426596/1097/1/012151

López, J., \& Whittington, M. S. (2001). Higher-Order Thinking In a College Course: A Case Study. Annual NACTA Conference, 2229.

Manalu, A. C. S., \& Zanthy, L. S. (2020). Analisis Kesalahan Siswa SMP Kelas IX dalam Menyelesaikan Soal Materi Lingkaran. Jurnal Cendekia: Jurnal Pendidikan Matematika, 4(1), 104-112.

Masitoh, L. F., \& Aedi, W. G. (2020). Pengembangan Instrumen Asesmen Higher Order Thinking Skills (HOTS) Matematika di SMP Kelas VII. Jurnal Cendekia: Jurnal Pendidikan Matematika, 4(2), 886-897.

Megawati, Wardani, A. K., \& Hartatiana. (2020). Kemampuan Berpikir Tingkat Tinggi Siswa SMP dalam Menyelesaikan Soal Matematika Model PISA. Jurnal Pendidikan Matematika, 14(1), 15-24. 
Noprinda, C. T., \& Soleh, S. M. (2019). Pengembangan Lembar Kerja Peserta Didik (LKPD) Berbasis Higher Order Thinking Skill (HOTS). Indonesian Journal Of Science and Mathematics Education, 02(2), 168-176.

Nurhikmayati, I., \& Jatisunda, M. G. (2019). Pengembangan Bahan Ajar Matematika Berbasis Scientific yang Berorientasi pada Kemampuan Berpikir Kritis Matematis Siswa. Mosharafa: Jurnal Pendidikan Matematika, 8(1), 49-60.

Prasetyo, W. (2012). Pengembangan Lembar Kegiatan Siswa (LKS) dengan Pendekatan PMR Pada Materi Lingkaran di Kelas VIII SMP N 2 Kepohbaru Bojonegoro. Jurnal MATHEdunesa, 1(1), 1-7.

Prastowo, W. (2012). Panduan Kreatif Membuat Bahan Ajar Inovatif. Yogyakarta: Diva Press.

Purwasi, L. A. (2019). The Development Of Higher-Order Thinking Skills On Junior High School Students Through Guided Inquiry-Based Learning Approach. Jurnal Pendidikan Matematika dan IPA, 10(2), 311-322.

Ramos, J. L. S., Dolipas, B. B., \& Villamor, B. B. (2013). Higher Order Thinking Skills and Academic Performance in Physics of College Students : A Regression Analysis. International Journal of Innovative Interdisciplinary Research, 4, 48-60.

Retnoasih, N. (2018). Implementasi Pembelajaran HOTS (Higher Order Thinking Skill) IPA Menggunakan Alat Sederhana. Jurnal Penelitian Pendidikan Matematika Dan Sains (JPPMS), 2(2), 48-53.
Sari, R. I., \& Wulandari, S. S. (2020). Pengembangan Lembar Kegiatan Peserta Didik (LKPD) Berbasis Pendekatan Saintifik Mata Pelajaran Humas dan Keprotokolan Semester Gasal Kelas XI OTKP di SMK YPM 3 Taman. Jurnal Pendidikan Administrasi Perkantoran (JPAP), 8(3), 440-448.

Supadma, I. K., Kusmariyatni, N. N., \& Margunayasa, I. G. (2019). Pengembangan Perangkat Pembelajaran Inkuiri Terbimbing Berbasis Aktivitas HOT Pada Tema 9 Subtema 1 Kelas IV SD. Jurnal Riset Pendidikan Dasar, 2(2), 106-115.

Tonra, W. S., Budiarto, M. T., Masriyah, \& Tonra, W. S. (2019). Profile of High Order Thingking Skill ( HOTS ) of Junior High School Students ' Grade 8 in Solving Linear Equation System Problems Based on Kinesthetic and Visual Learning Styles. International Journal of Trends in Mathematics Education Research, 2(4), 212-214.

Trianto. (2009). Mendesain Model Pembelajaran Inovatif-Progresif. Surabaya: Kencana.

Umbaryati. (2016). Pentingnya LKPD pada Pendekatan Scientific Pembelajaran Matematika. PRISMA: Prosiding Seminar Nasional Matematika, 217-225.

Utari, T., Hobri, \& Oktavianingtyas, E. (2017). Pengembangan Lembar Kerja Siswa (LKS) Matematika Berorientasi Scientific Approach Untuk Menumbuhkan Kemampuan Higher Order Thinking (HOT) Pokok Bahasan Persamaan Lingkaran Pada Siswa SMA Kelas XI. Jurnal Kadikma, 8(2), 13-23. 
DOI: https://doi.org/10.24127/ajpm.v9i4.3172

Widana, I. W., Parwata, I. M. Y., Parmithi, N. N., Jayantika, I. G. A. T., Sukendra, K., \& Sumandya, I. W. (2018). Higher Order Thinking Skills Assessment towards Critical Thinking on Mathematics Lesson. International Journal of Social Sciences and Humanities (IJSSH), 2(1), 24-32.

Wulandari, T. N., \& Susanti. (2019). Pengembangan Lembar Kegiatan Peserta Didik (LKPD) Berbasis Higher Order Thinking Skills (HOTS) pada Mata Pelajaran Akuntansi Perbankan Syariah Kelas XI Semester I di SMK. Jurnal Pendidikan Akuntansi, 7(3), 347-252.
Yuliandini, N., Hamdu, G., \& Respati, R. (2019). Pengembangan Soal Tes Berbasis Higher Order Thinking Skill (HOTS) Taksonomi Bloom Revisi di Sekolah Dasar. PEDADIDAKTIKA: Jurnal Ilmiah Pendidikan Guru Sekolah Dasar, 6(1), 37-46.

Zulkardi, Z., \& Putri, R. I. I. (2020). Supporting Mathematics Teachers to Develop Jumping Task Using PISA Framework (JUMPISA). Jurnal Pendidikan Matematika, 14(2), 199-210. 